\title{
As Universidades Gaúchas Estão Preparando o Futuro
}

ALBERTO ANDRE

Diretor da Faculdade de Meios de Comunicação Social da PUC

Com nove universidades e pelo menos 15 faculdades isoladas, o Rio Grande do Sul está em posição excepcional no momento brasileiro. Seus 35.000 estudantes de nivel superior significam proporção razoável quanto à população e ao território, que se espalha da capital e do planalto à serra.

Comparativamente, o Estado, em cursos superiores, vem depois de São Paulo e Minas Gerais, mas em percentual sôbre o ensino médio consegue levar para as classes superiores mais de $10 \%$ dos 341.240 secundaristas, indice semelhante ao de São Paulo e maior do que o de Minas Gerais, que estão respectivamente com 1.248 .100 - 510.000 secundaristas, e 127.030 e 49.646 superiores. Êsses elementos São estimativas do IBGE para 1970, enquanto os do Rio Grande do Sul são composições do Departamento Estadual de Estatística. No conjunto, são apenas previsões, mas servem para orientar pesquisa ou informação, na expectativa do censo geral que se aproxima.

\section{DISTRIBUIÇÃO}

Examinando-se a colocação das universidades gaúchas e instituições iso- ladas, aceita-se logo a posição otimista. "Nosso Estado é dos mais bem servidos" - afirmou o professor Elvo Clemente, secretário-geral da Pontifícia Universidade Católica do Rio Grande do Sul.

O maior complexo educacional do Sul do País é, sem dúvida, a Universidade Federal do Rio Grande do Sul, que possui o maior número de institutos e faculdades, o moderno Hospital de Clínicas e 8.900 alunos, com orçamento de meia centena de milhões de cruzeiros. Em seguida, a PUC, com seu campus de 14 prédios e vários outros em construção, na sua Cidade Universitária localizada no Partenon, a oito quilômetros do centro da capital, onde estão 7.600 estudantes. A Universidade Federal está também projetando a sua Cidade Universitária, em área de 2.000 hectares, na Agronomia, nos limites de Viamão. A primeira fase será a ocupação de área de 60 hectares para 12.000 acadêmicos.

As sete outras universidades estão distribuídas pelo interior. A mais próxima de Pôrto Alegre é a Universidade do Vale do Rio dos Sinos, em São Leopoldo, com 3.200 matrículas. A mais 
afastada é a Universidade de Passo Fundo, a $326 \mathrm{~km}$ da capital, com 2.750 alunos, seguindo-se-lhe a Universidade Federal de Santa Maria, a $303 \mathrm{~km}$, no coração do Rio Grande. Ela está localizada em um magnifico campus, o de Camobi, e tem 3.500 estudantes. Pelotas, a $250 \mathrm{~km}$ de Pôrto Alegre, tem duas universidades, a Católica, com 2.150 alunos, e a Federal, com 1.200. Eis as outras: Caxias do Sul, plantada na região serrana com 2.800; e Rio Grande, de criação recente, com 1.400 estudantes.

Com referência à manutenção, três são federais e seis particulares, estas administradas por entidades associativas ou religiosas.

\section{IRRADIAÇÃO}

Além das universidades, convém assinalar a formação de núcleos em diferentes pontos do Estado, em que se anotam tendências universitárias. Êsses núcleos constituem irradiações das universidades existentes ou de projeção local. Entendidos garantem que, não havendo maiores óbices, três ou quatro novas universidades poderão surgir nos anos vindouros.

A Universidade Federal de Santa Maria, por exemplo, avançou seus postos, no exercício de 1969, para núcleos em Santa Cruz, Santa Rosa, Três de Maio e São Gabriel, além de sua Faculdade de Educação, na própria Santa Maria, ter sido transformada em estabelecimento latino-americano.

A Universidade de Caxias do Sul, na região do vinho, estendeu-se para Vacaria, Bento Gonçalves e Lajeado. Canoas e Taquara são núcleos da Universidade do Vale do Rio dos Sinos. A PUC, de Pôrto Alegre, já está em Uruguaiana, na fronteira, e Santa Rosa, nas Missões; e a Universidade de Passo Fundo foi para Erexim e Palmeiras. Há núcleos de duas ou mais faculdades em Bagé, Uruguaiana, Alegrete, Santo Ångelo, Cruz Alta e Santa Rosa. Finalmente, inaugurou-se êste ano, com 370 alunos, a Federação das Faculdades de Nôvo Hamburgo, a zona do calçado.

No conjunto, êstes aspectos, no princípio, foram apreciados sob a facêta da "proliferação de universidades e faculdades, sem adequação ao mercado de trabalho ou às conveniências do mestrado". Ûltimamente, não mais se ouvem críticas e a situação se estabiliza. "O resultado de tudo isso? Uma coisa é certa: teremos gerações preparadas, mais aptas a enfrentar os trabalhos e as exigências do desenvolvimento nestas vastas e prósperas regiões do Brasil" - concluiu o professor Irmão Elvo Clemente.

\section{PROFISSIONAIS}

O número de professôres de ensino superior é de, aproximadamente, 4.500, mas não há como indicar os de tempo integral. Diplomam-se anualmente 4.000 profissionais liberais nas diferentes atividades, a calcular-se pelo registro dos diplomas na Universidade Federal do Rio Grande do Sul, que recebeu delegação do MEC.

Pesquisa do Centro de Estudos e Treinamento dos Recursos Humanos, realizada sob a coordenação de Rubens Pôrto, convênio do MEC com a Fundação Getúlio Vargas, o Rio Grande do Sul tem 21.345 profissionais liberais atuando em seu território, em 1969, sôbre 230.074 para todo o Brasil. São Paulo vai à frente, com 62.321, seguido da Guanabara, com 53.162, $\theta$ de Minas Gerais, com 22.751. Esse levantamento abrange as profissőes de 
advogado, agrônomo, arquiteto, dentista, economista, engenheiro, farmacêutico, médico e veterinário. A pesquisa foi minuciosa, descendo aos municiplos, 3.939 no Brasil. Algumas profissões de nível superior, porém, não foram incluidas, como a dos contabilistas.

Não há elementos para cotejar as profissões superiores com as de nível técnico e primário. Fica, aqui, para indagação, a migração de liberais entre as unidades do País. O último reparo, finalmente, diz respeito a aspecto que não é só do Rio Grande, mas do Brasil inteiro: são êsses profissionais bem preparados?

\section{INTEGRAÇAO REGIONAL}

As angústias dos estudantes universitários gaúchos, dos professôres e dirigentes das universidades são as mesmas das demais unidades da Federaఢ̧ão. As universidades passam por uma reforma, são contestadas e buscam conteúdo que as harmonize com os tempos.

O Reitor da Universidade Federal do Rio Grande do Sul, Eduardo Faraco, pondera num dos seus relatórios: "Aos estudantes, quero dizer que a Universidade saberá compreender seus anselos e corresponder às suas justas esperanças".

O Reitor da UFRGS está apressando a reforma universitária, mas depende de espaço, o que conseguirá com o campus projetado em área a 12 quilômetros do centro, na Agronomia. Grupo de técnicos ultima os projetos da primeira fase da Cidade Universitária.

Para o diretor do Departamento de Educação e Cultura da UFRGS, Jorge Furtado, "estamos fazendo o máximo para projetar a universidade no desenvolvimento, na comunidade, na emprêsa e em todos os lugares onde deva atuar".

Para tanto, o Departamento de Educação e Cultura encaminha amplo programa, desde a educação cívica e fisica até a comunicação, em que se jogam instrumentos de radiodifusão, computadores, editoração, entretenimento, artes e o mais que possa servir à integração do homem da década de 70.

Por sua vez, o Reitor da PUCRGS, professor Irmão José Otão, tem a firme convicção da "vitória da universidade no cumprimento da sua função nestes dias tumultuados". Assinala que "todos, da área pública ou privada, estão hoje convencidos de que a única opção é em função do homem em sua integridade espiritual e social. O Rio Grande do Sul orienta sua universidade para dois caminhos básicos: 1) - preparando homens que devem ensinar; 2) - adotando, na medida do possivel, o tempo integral".

O tempo integral está sendo conceituado como fator relevante na modernização das universidades sulinas. $\mathrm{Na}$ área pública o tempo integral vai sendo executado em setores tecnológicos. Na privada, aponta-se o convencimento de que não haverá ajuda financeira governamental, pelo que devem as universidades suprir a falta. $O$ rumo será então o do tempo integral, através de faixas, podendo os professôres ficar a serviço da universidade durante a manhã, a tarde ou a noite, o que decide em parte $O$ assunto.

A universidade rio-grandense prepara-se para a integração regional com Santa Catarina e Paraná, sob os esfor- 
ços dos seus reitores e o ostensivo interêsse dos órgãos federais de planejamento. Sua reforma se acentua, os cursos de pós-graduação aumentam, o treinamento efetivo ganha projeçőes, seus mestres recebem mais a experiência interna e externa.

Pelos elementos obtidos, ela progride, embora não seja encorajador o fato de que apenas 10 ou $11 \%$ dos aprovados no secundário possam ter acesso ao escalão superior. $O$ equipamento ainda é escasso, mas sente-se a consciência do que tem de ser feito, das dificuldades e dos objetivos a superar. A universidade gaúcha trabalha para vencer a sua etapa no desenvolvimento nacional. 